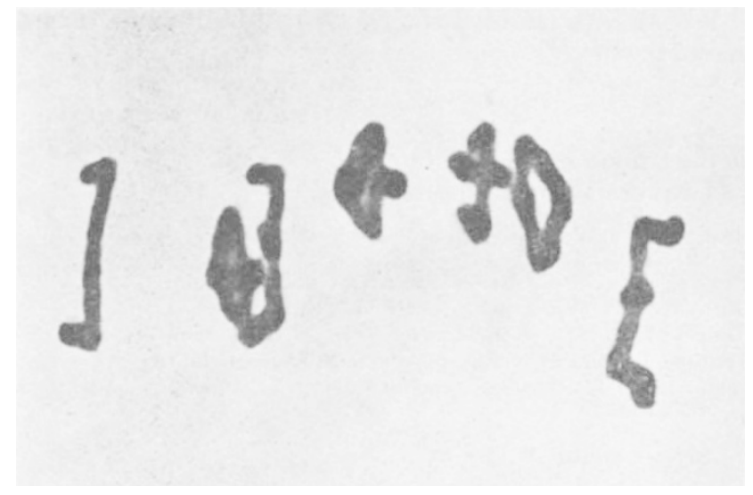

Fig. 3. First meiotic metaphase in a pollen mother cell of the Lolium hybrid showing asymmetrical bivalents. $(x 1,750)$

cells of the hybrids. At pachytene unpaired loops indicating deficioncy or excess of genetic material are frequent. At metephase the persisting inequality of chromosome size is manifested by the distinct asymmetry of up to six of the bivalents (Fig. 3). These asymmetrical bivalents are, with respect to long and short arms, orientated at random. There is no evidence for 'affinity'.

There may well be a causal relation between the variation in the amount of genetic material in the two species and the difference in their breeding systems. We have no evidence to show whether this is so, or how it may operate.

We wish to thank Mr. Beddows, of the Welsh Plant Breeding Station, Aberystwyth, for seeds of $L$. temulentum.

Agricultural Research Council

BERYL NAYLOR

H. REES

Unit of Biometrical Genetics,

Department of Genetics,

University of Birmingham. Jan. 3.

Jenkin, T. J., J. Genet., 52, 300 (1954). - Thomas, P. T. Ph.D. thesis, University College of Wales, Aberyst-

'Darlington, C. D., "Recent Advances in Cytology" (1937).

- Thomas, P. T., Nature, 138, 402 (1936).

\section{Fortifying Influences of Coconut Milk and Cow's Urine on 2,4-Dichlorophenoxy- acetic Acid in the Control of Button Shedding in the Coconut}

DURING several trials carried out by us with different hormones in the control of button shedding in the coconut, there was clear indication that, while sprays of 2,4-dichlorophenoxyacetic acid in 30 p.p.m. strength helped in securing a heavy set of buttons, quite a large number of them turned out to be abnormal or barren and markedly reduced in size when they attained maturity. This was observed to be particularly pronounced when pre-fertilization sprays were given. Although a change from prefertilization to post-fertilization sprays brought about a considerable reduction in the occurrence of abnormal and barren nuts and an appreciable improvement in the size of nuts at maturity, it did not help in com. pletely offsetting the defects. It was therefore thought worth while to test the utility of coconut milk and cow's urine in overcoming these defects, since these might, by virtue of their growth-promoting properties, be expected to fortify the action of 2,4-dichlorophenoxyacetic acid, acting synergistically ${ }^{1}$ or in some other way.

Preliminary trials were accordingly undertaken by using mixtures of coconut milk or cow's urine (which by themselves were inactive in improving button setting) with equal volumes of 2,4-dichlorophenoxyacetic acid in order to ascertain to what extent these would serve as an improvement. The results of these trials have indicated the interesting beneficial effect in using the mixtures, as these have not only helped to increase the percentage set of nuts and their overall development, but also reduced the incidence of barren nuts compared with the results secured with sprays of 2,4-dichlorophenoxyacetic acid alone, as may be seen from the results presented in Table 1 .

Table 1

\begin{tabular}{|c|c|c|c|c|}
\hline $\begin{array}{l}\text { Characters } \\
\text { determined }\end{array}$ & $\begin{array}{l}\text { Control } \\
\text { (water } \\
\text { spray) }\end{array}$ & $\begin{array}{l}\text { Sprays of } \\
2,4-D \\
\text { alone }\end{array}$ & $\begin{array}{l}\text { Sprays of } \\
2,4-D \\
\text { mixed } \\
\text { with coco- } \\
\text { nut milk }\end{array}$ & $\begin{array}{c}\text { Sprays of } \\
2,4-D \\
\text { mixed } \\
\text { with cow's } \\
\text { urine }\end{array}$ \\
\hline $\begin{array}{l}\text { Mean percentage } \\
\text { set of good nuts } \\
\text { Mean No. of un- }\end{array}$ & $7 \cdot 62$ & $26 \cdot 20$ & $44 \cdot 83$ & $31 \cdot 23$ \\
\hline $\begin{array}{l}\text { der developed } \\
\text { nuts }\end{array}$ & 0.00 & $9 \cdot 66$ & $4 \cdot 33$ & $4 \cdot 66$ \\
\hline $\begin{array}{l}\text { Mean vol. per nut } \\
\text { (ml.) }\end{array}$ & 2158.29 & $161 \mathrm{~A}, \mathrm{A7}$ & $? 272: 29$ & 930.83 \\
\hline Mean wt. per nut & $2,108 \cdot 30$ & $1,010.08$ & $2,375.38$ & $2,360 \cdot 83$ \\
\hline $\begin{array}{l}\text { (gm.) } \\
\text { Mean wt. of copra }\end{array}$ & $903 \cdot 33$ & $619 \cdot 00$ & $745 \cdot 40$ & $731 \cdot 00$ \\
\hline per nut (gm.) & $171 \cdot 67$ & $135 \cdot 00$ & $152 \cdot 50$ & $150 \cdot 33$ \\
\hline
\end{tabular}

2,4-D = 2,4-dichlorophenoxyacetic acid

It is quite clear that there is a significant fortifying influence when 2,4-dichlorophenoxyacetic acid was used with a supplement of coconut milk or cow's urine and that the former proved to be superior in its synergistic effect than the latter.

Further trials are in progress to evaluate the beneficial effects of these and similar other mixtures on a statistical basis. We thank Dr. K. P. V. Menon for his interest in the work and Mr. T. P. Gopalakrishnan for his technical assistance.

\section{S. R. Gangolly}

K. M. Pandalai

Central Coconut Research Station,

Kasaragod, South India.

Dec. 5.

'Steward, F. C., and Caplin, S. M. Science, 108, $655(1948) ; 118$

518 (1951); Ann. Bot., N.S., 16, 491 (1952).

\section{An Infectious Fertility Factor for Pseudomonas aeruginosa}

ONE unusual feature of the system of sexual recombination occurring in Escherichia coli is the infectious nature of the $F$ factor. $F$ - atrains may be readily converted to $F+$ by growing the two types together ${ }^{1,2}$.

A similar type of sexual recombination to that occurring in $E$. coli occurs in Pseudomonas aeruginosa ${ }^{3,4}$. Two of the Pseudomonas strains used, 1 and $L$, are interfertile. Furthermore, 1 is self-sterile but $L$ is self-fertile with a lower frequency of recombination than the $1 \times L$ combination. This situation is comparable to the fertility system occurring in $E$. coli K12. Strain 1 is the equivalent of the $F-$ strain, strain $L$ the equivalent of the $F+$. Previous attempts to find an infectious fertility factor in Pseudomonas 